\title{
NEVHODNĚ NAVRŽENÉ STAVEBNÍ PRVKY VERSUS VIDEOANALÝZA KONFLIKTNÍCH SITUACÍ
}

\author{
INAPPROPRIATELY DESIGNED BUILDING ELEMENTS VERSUS \\ VIDEO ANALYSIS OF CONFLICT SITUATIONS
}

\author{
doc. Ing. Vladislav Kr̈ivda, Ph.D.; doc. Ing. Ivana Mahdalová, Ph.D.; \\ Ing. Jan Petrů, Ph.D.
}

\begin{abstract}
ABSTRAKT
Článek se zabývá stručným popisem sledování konfliktních situací v silničním provozu v ČR i v zahraničí. Popisuje původní metodiku videoanalýzy konfliktních situací vytvořenou v 70. letech 20. století. Hlavní část článku je věnována využití videoanalýzy konfliktních situací při hodnocení nevhodně navržených stavebních prvků na křižovatkách.
\end{abstract}

Klíčová slova: silniční doprava, konfliktní situace, bezpečnost silničního provozu

\section{ABSTRACT}

This paper deals with of brief description of monitoring of road traffic conflict situations in the Czech Republic and abroad. It describes origin methodology of video analysis of conflict situations created in the 70s of the 20th century. The main part of this article is devoted to the use this method for assessment of inappropriately designed building elements on intersections.

Key words: Road Transport, Conflict Situation, Road Traffic Safety

\section{1 ÚVOD}

Každá pozemní komunikace, resp. její konstrukce musí splňovat přísná kritéria pro zachování bezpečného a plynulého provozu. Spolehlivost takové konstrukce je mj. ovlivněna zatížením a to jednak zatížením, které vytvářejí automobily svou hmotností (např. riziko tvorby vyjetých kolejí na vozovce) a jednak tzv. dopravním zatížením, reprezentovaným intenzitou dopravních proudů. Vysoké intenzity dopravy pak mohou vyvolávat nestandardní chování účastníků silniční dopravy a tím zvýšený počet nebezpečných situací. Tyto situace mohou vyústit v dopravní nehodu a je pak otázkou, zda se jí dalo, či nedalo zabránit. K nehodě může dojít jednak vlivem nepozornosti řidiče (účastníka provozu) a jednak „chybnou infrastrukturou“ (např. nevhodně navržená pozemní komunikace, křižovatka, přechod pro chodce atp.), která zapříčiní špatné chování řidiče a následný problém, tj. např́iklad tzv. konfliktní situaci (skoronehodu) nebo př́mo dopravní nehodu.

Konfliktní situace je takový okamžik či situace v silničním provozu, kdy vzniká, resp. může vzniknout, pro některé účastníky větší než obvyklá míra nebezpečí [4]. Každé dopravní nehodě musí samožrejmě předcházet právě konfliktní situace, jež lze také nazývat jako tzv. skoronehodu. Naopak lze tedy ř́ci, že každá dopravní nehoda je důsledek takové konfliktní situace, kdy se nepodařilo míru nebezpečí střetu odvrátit. Konfliktní situace jsou tedy potenciální nehodové situace a jejich typ pak předurčuje typ dopravní nehody.

Statistiky dopravní nehodovosti nám dávají jistý přehled o počtech a příčinách dopravních nehod, statistiky konfliktních situací však logicky neexistují. V př́padě potřeby je tedy nutno provést analýzu 
chování účastníků provozu na místě samém, a to např. s využitím videoanalýzy konfliktních situací. Cílem tohoto př́spěvku je tedy poukázat na možnost využití této metody při sledování těch konfliktů, které mohou být př́činou dopravních nehod, u kterých dochází $\mathrm{k}$ narušování stavebních prvků křižovatek s tím, že tato metoda byla vyvinuta v rámci odborné činnosti na Fakultě stavební, VŠB-TU Ostrava [8] a jako taková je zde přednášena studentům, kteří ji využívají mj. pro řešení svých závěrečných prací. Použití videoanalýzy konfliktních situací však může také sloužit projektantům dopravních staveb, aby se vyvarovali některých chybných návrhů při projektování křižovatek. Využijí ji rovněž auditoři bezpečnosti pozemních komunikací při bezpečnostních inspekcích.

\section{STRUČNÝ VÝVOJ SLEDOVÁNÍ KONFLIKTNÍCH SITUACÍ}

Počátky sledováním konfliktních situací sahají do 60. let minulého století, kdy Perkins a Harrish [10] zaznamenávali na základě vizuálního pozorování situace na vstupních ramenech do křižovatky. Zapisovány byly však pouze ty situace, při kterých došlo bud' k výraznému vybočení z jízdního pruhu, nebo k prudkému zabrzdění (to bylo evidováno rozsvícením brzdových světel). Tímto postupem se poté zabývali také další autoři jako např́klad Bennet, Baker, Hayward, Rustam a Sabey (viz [2], [3], [6] a [11]).

Konfliktní situace byly předmětem sledování i v tehdejším Československu. Počátkem 70 . let 20. století se pozorování chování účastníků dopravy začal zabývat doc. Ing. Jan Folprecht, Ph.D. z Ústavu silniční a městské dopravy v Praze, který si uvědomil, že typů konfliktních situací je mnohem více než analyzovali dopravní inženýři ze zahraničí. Uvědomil si také, že pro získání objektivnějších výsledků je vhodné využití videotechniky (více viz následující kapitola). Po nástupu doc. Folprechta na VŠB-TU Ostrava (konkrétně na Institut dopravy Fakulty strojní) se začátkem 90. let začala tato metoda využivat i na tomto pracovišti a to především při pedagogické činnosti. $\mathrm{V}$ rámci mezifakultní spolupráce a přestupu některých pracovníků mezi pracovišti se videoanalýza konfliktních situací začala využívat při pedagogické, odborné i publikační činnosti na Katedře dopravního stavitelství Fakulty stavební VŠB-TUO. Výsledkem je řada závěrečných prací studentů všech forem studia i odborných výsledků (články v odborných časopisech, využití v projektech atp.). Původní metodika doc. Folprechta se tak mohla dále rozvíjet a některé počiny, týkající se využití videoanalýzy konfliktních situací při hodnocení nevhodně navržených stavebních prvků na křižovatkách [8], jsou patrné z tohoto článku.

Jako další odborníky, kteří se zabývají, příp. zabývali sledováním konfliktních situací, lze jmenovat např. doc. Slabého [12], doc. Kocourka [7], Ing. Ambrose [1], Ing. Zajíce [13] a další. Zajímavým počinem je vznik metodiky [1], která využívá různých způsobů sledování dopravních konfliktů a je pravděpodobně $\mathrm{v}$ dnešní době jediným uceleným a certifikovaným dokumentem $\mathrm{v}$ ČR pro tuto problematiku.

\section{VIDEOANALÝZA KONFLIKTNÍCH SITAUCÍ DLE FOLPRECHTA}

Významným počinem, který uskutečnil doc. J. Folprecht při sledování konfliktních situací pomocí videoaparatury, bylo rozdělení těchto situací dle jejich závažnosti. Proto doc. J. Folprecht zvolil tři stupně závažnosti konfliktních situací a to takto [4]:

- I. stupeň - situace, kdy jde o porušování dopravních předpisů v té chvíli osamoceným účastníkem silničního provozu, tj. bez přítomnosti jiných, které by mohl omezit či ohrozit (jde o tzv. potenciální konfliktní situaci), 
- $\quad$ II. stupeň - situace, kdy lze pozorovat jisté narušení plynulosti provozu, tzn. situace, které sice nevyvolávají násilnou reakci dalších účastníků, ale váhání, agresivita či prosté chybné jednání je zřejmé a má za následek reakci dalších účastníků,

- $\quad$ III. stupeň - situace, kdy jedině prudká úhybná reakce (ostré brzdění nebo náhlé vybočení) zamezí střetu.

$\mathrm{Na}$ základě bohatých zkušeností stanovil doc. J. Folprecht postup při sledování a hodnocení konfliktních situací s využitím videoaparatury [4]. Nejdříve se pořídí videozáznam vybraného místa, kde má být silniční provoz analyzován, a to pokud možno z co nejvyššího místa. Statisticky průkazný soubor konfliktních situací je možno získat již z hodinového záznamu [5] - nicméně záleží na povaze provozu, typu pozorovaného místa atp. a v př́padě potřeby je nutné sledovat delší záznam. Je nezbytné, aby videozáznam vyhodnocovalo více osob současně. Jednak se tím zrychlí samotné vyhodnocování a jednak výsledky budou objektivnějšsí, než v př́ípadě sledování jediným pozorovatelem. Sledování videozáznamu je však omezeno na maximálně tři hodiny [4], jelikož po této době již klesá soustředěnost a dochází $\mathrm{k}$ chybným úsudkům.

Při vyhodnocování se využivá možnost záznam zastavit, zpomalit, resp. opakovat, v čemž vlastně spočívá jádro výhody použité technologie. Ze záznamu lze navíc zaznamenat další charakteristiky silničního provozu v daném místě, tj. např́klad intenzita a složení dopravního proudu atp. Soubor vybraných dopravních charakteristik společně se souborem zaznamenaných konfliktních situací pak tvoří datovou základnu určující charakter provozu na daném místě.

Vysledované konfliktní situace zaznamenával doc. J. Folprecht do půdorysného schématu dané lokality, jak ukazuje obr. 1. Tímto způsobem se velmi dobře ožrejmí místa jejich kumulací a tím také jejich př́ičiny. Lze pak vyvodit i př́ípadný způsob možných následných opatření $\mathrm{k}$ zabránění vzniku těchto konfliktů. Četnost výskytu konfliktních situací je pak ukazatelem váhy (míry vlivu) př́íčin, které logicky vyplývají z typů konfliktních situací [4]. Projektant dopravních staveb tak může již pouhým posouzením těchto výstupů provést, $\mathrm{s}$ cílem zlepšit organizaci dopravy, odpovědný návrh na úpravu uspořádání.

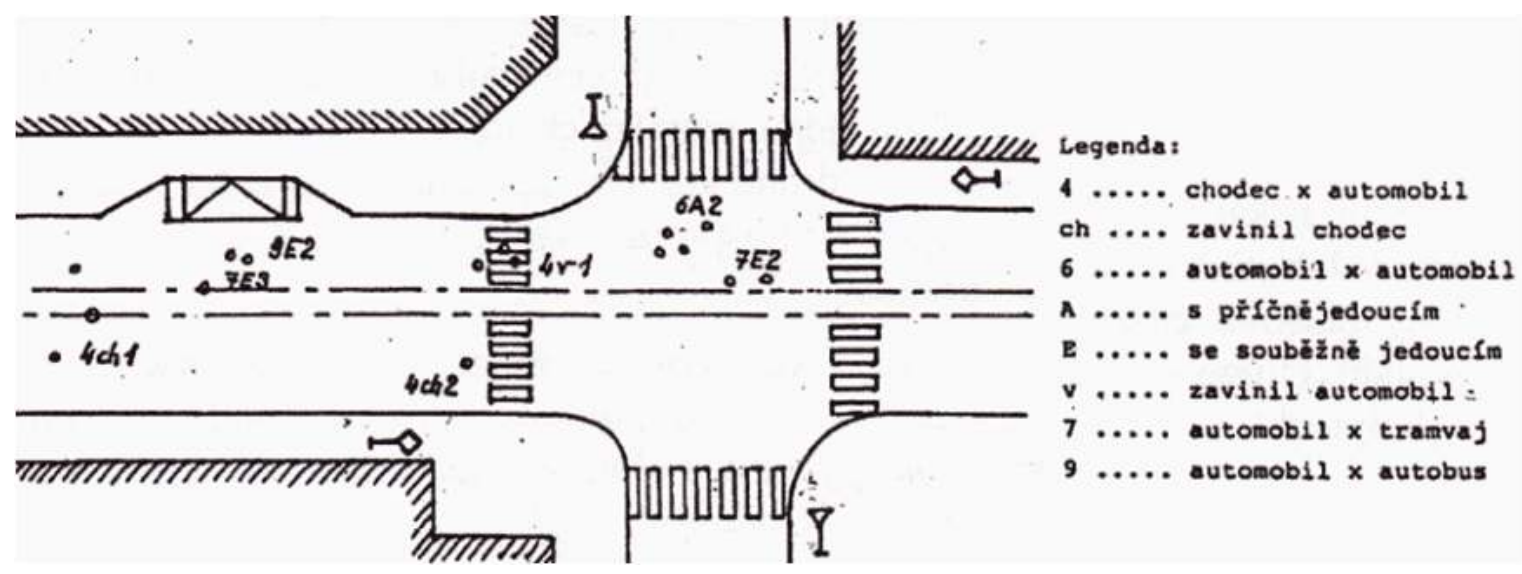

Obr. 1 Př́iklad grafického zpracování videoanalýzy podle doc. J. Folprechta [4]

Podrobnosti o Folprechtově metodě lze nalézt například v [5] a [8], př́padně lze kontaktovat přímo autory tohoto článku. 


\section{VYUŽITÍ VIDEOANALÝZY KONFLIKTNÍCH SITUACÍ PŘI HODNOCENÍ NEVHODNĚ NAVRŽENÝCH STAVEBNÍCH PRVKŮ NA KŘIŽOVATKÁCH}

Jako každá metodika i videoanalýza konfliktních situací prochází svým vývojem. V rámci výzkumné činnosti, jenž je shrnuta $\mathrm{v}$ [8], bylo nutno přistoupit $\mathrm{k}$ různým inovacím a to především při členění konfliktních situací. Podle příslušnosti vzniku dané konfliktní situace pak byly situace nově rozděleny na tzv. vlastní konfliktní situace (souvisí přímo s provozem na sledovaném místě, s jeho stavebním uspořádáním atp.) a na tzv. nevlastní konfliktní situace (nesouvisí př́mo s provozem na sledovaném místě, s jeho stavebním uspořádáním atp. a vzniknou mimo sledované místo).

Další rozdělení souvisí s alternativou, kdy konfliktní situace vznikne v důsledku jiné situace a samy o sobě by pravděpodobně nevznikly. Konfliktní situace pak dělíme na tzv. prvotní konfliktní situace (nejsou vyvolány jinou situací) a na tzv. následné konfliktní situace (jsou vyvolány jinou situací (zpravidla prvotní, nebo př́ípadně i jinou následnou situací).

Vzhledem k tomu, že důvod vzniku některých konfliktních situací není zapříčiněn pouze chybným chováním řidiče (resp. jiného účastníka silničního provozu), ale na vzniku těchto situací nese svým způsobem vinu i např. stavební uspořádání sledovaného místa, bylo potřeba konfliktní situace rozdělit následujícím způsobem. První skupinu tvoří tzv. provozní konfliktní situace (zapříčiněné pouze samotným řidičem, resp. jiným účastníkem silničního provozu), druhou pak tzv. stavební konfliktní situace (zapříčiněné nejen samotným řidičem, ale také - mnohdy především - nevhodně navrženými stavebními prvky). Do provozních situací můžeme zařadit například nedání přednosti v jízdě, jízda na červenou, nebezpečí najetí zezadu atp. Mezi stavební konfliktní situace řadíme například jízdu v těsné blízkosti obrubníků, najetí do protisměru při výjezdu z křižovatky atp., ale pouze dojde-li k těmto situacím také vinou nevhodně navržených stavebních prvků! Jde-li o situaci, které šlo zabránit a která tedy vznikla pouze chybným chováním řidiče, měla by být tato situace zařazeno do skupiny provozních konfliktních situací.

Na základě zkušeností ([8], [9]) lze konstatovat, že pro sledování a následnou analýzu provozních konfliktních situací je v podstatě dostačující použití tzv. základního videozáznamu z pozorovacího místa umístěného pokud možno v co nejvyšší poloze (podle doporučení původní metodiky doc. Folprechta). Pro sledování a analýzu stavebních konfliktních situací je ale potřeba doplnit základní videozáznam dalším tzv. detailním videozáznamem, který je pořízen v těsné blízkosti problematického stavebního prvku. Postup při hodnocení nevhodně navržených stavebních prvků na křižovatkách je následující ([8] - výrazně zestručněno):

1. Vytipování problémové křižovatky na základě vlastního pozorování a zkušeností, podnětů občanů (řidičů), provedení ověření průjezdnosti křižovatky pomocí vlečných křivek atp.

2. Monitoring na místě podle identifikačních znaků jako například porušené obrubníky, stopy od pneumatik projíždějících vozidel na obrubnících, poškozené směrové sloupky, pojížděním neznatelné vodicí čáry atp.

3. Pořízení videozáznamu celé křižovatky (tzv. základní videozáznam) pro získání celkového obrazu provozu na křižovatce s vytipováním problémových míst.

4. Pořízení detailních videozáznamů míst, kde na základě vyhodnocení základního videozáznamu je evidentní nebezpečí vzniku stavebních konfliktních situací, nebo míst, kde lze tyto situace předpokládat. Kamera je umístěna v úrovni křižovatky v místě, odkud je na inkriminované místo nejlépe vidět. Body 3 a 4 se mohou provést i současně.

5. Vyhodnocení videozáznamů bud' zjednodušeným způsobem (tj. prostá základní analýza provozu z běžícího videozáznamu - viz obr. 2) nebo podrobnou analýzou videozáznamu 
(tj. pomocí krokování po jednotlivých snímcích záznamu a porovnáním různých změn např. svislé polohy kola, které najelo na obrubník, vůči podběhu atp. - viz obr. 3).

6. Výsledky videoanalýzy lze pak zaznamenat tabelárně, kde jsou uvedeny přesně časy vzniku konfliktní situace, označení situací zvoleným klasifikačním symbolem, stručný popis vzniku konfliktní situace s případným upozorněním na důležité či zvláštní okolnosti atp. Součástí tabelárního vyhodnocení je pak uvedení údajů o četnosti konfliktních situací a, je-li potřeba, také ukazatelů relativní konfliktnosti (poměr počtu konfliktních situací a počtu projetých vozidel). Samožrejmostí by mělo být zpracování získaných údajů $\mathrm{s}$ využitím příslušných matematických a statistických metod.

7. Grafické vyhodnocení se pak provádí zakreslením konfliktních situací do půdorysného schématu (viz obr. 4). Je vhodné použít dvě schémata, přičemž na prvním je vhodnými značkami naznačeno co nejpřesněji místo vzniku konfliktní situace a počtem těchto značek pak četnost daného konfliktu. Na druhém schématu je pak schematický znázorněn průběh vzniku konfliktní situace, ze kterého je mj. zřetelný směr jízdy vozidel, místo vzniku konfliktu atp.

8. Samozrejmostí je shromáždění podrobné fotografické dokumentace a vytvoření videosekvencí konkrétních konfliktních situací.

9. V případě potřeby je vhodné provést ověření průjezdnosti daného místa s použitím vlečných křivek.

10. Závěrem by měl být proveden návrh na opatření za účelem zlepšení plynulosti dopravy a zvýšení bezpečnosti provozu na sledované křižovatce.
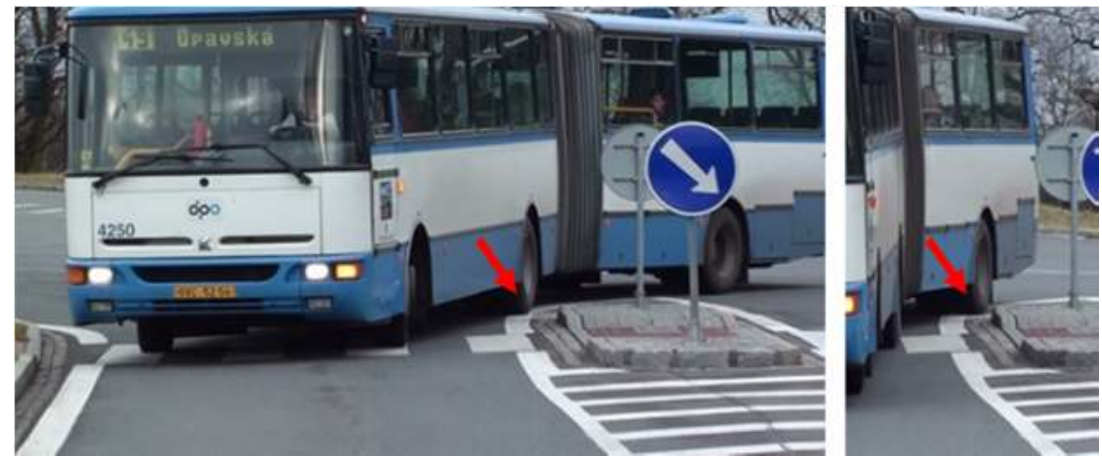

Obr. 2 Najetí autobusu na vodorovné značení, resp. do těsné blízkosti obrubníku ostrůvku [8]
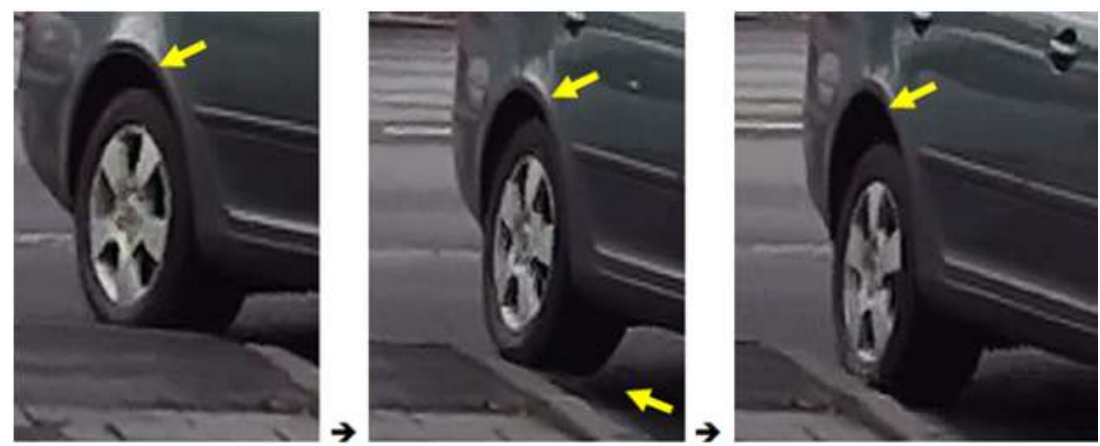

Obr. 3 Detail najetí vozidla na obrubník; levá fotografie ukazuje okamžik těsně

před najetím na obrubník, prostř̌ední fotografie okamžik, kdy už kolo na obrubník najelo a pravá fotografie pak okamžik sjetí kola zpět na vozovku - je zde patrná jednak mezera mezi pneumatikou a vozovkou (dolní šipka) a jednak změna velikosti mezery mezi pneumatikou a podběhem (horní šipky); mezi levou a pravou fotografií uplynulo 10/25 sekundy [8] 

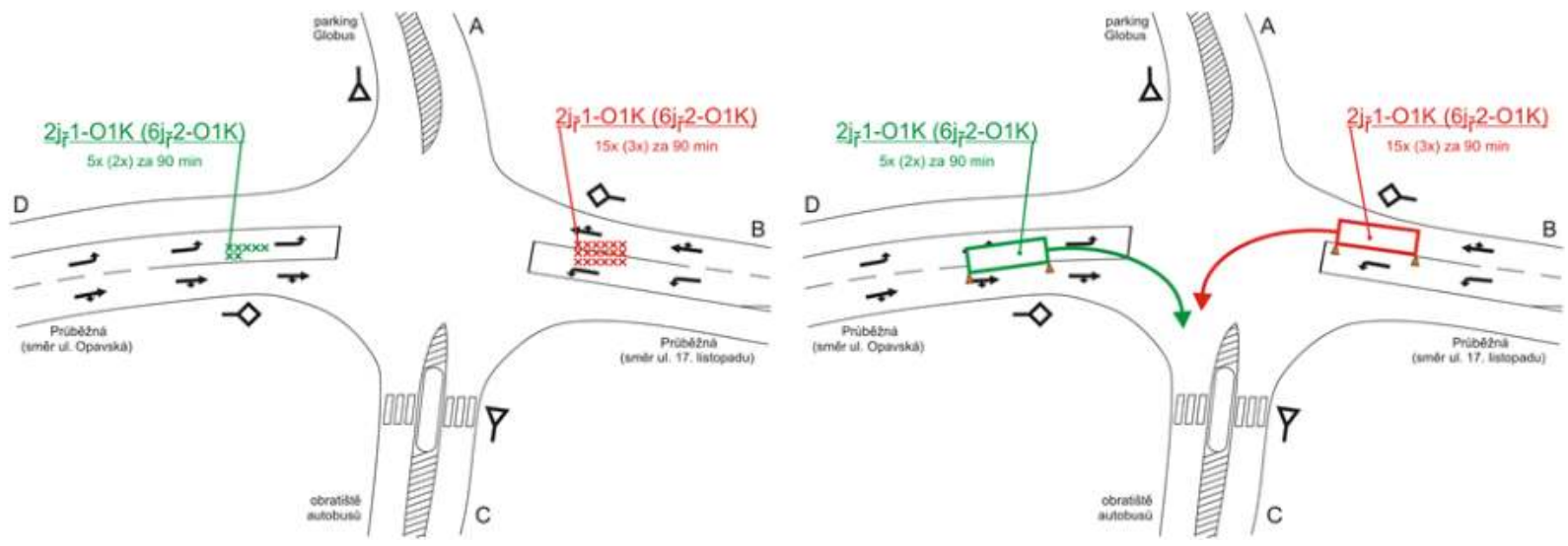

Obr. 4 Schéma vzniku a lokalizace dvou konfliktních situací - př́íklad [8]

\section{ZÁVĚR}

Dopravní nehodovost na silnicích v ČR podle statistik každým rokem sice klesá, nicméně z důvodu měnícího se způsobu sledování dopravních nehod (především co se týče povinnosti řidičů hlásit vznik nehody) nelze tyto výsledky brát jako srovnatelné s předchozími údaji. Průkaznější jsou již časové řady ukazující vývoj počtu zraněných či usmrcených, jelikož tyto nehody by měly být policii hlášeny a tudíž lze předpokládat, že se drtivá většina těchto dopravních nehod promítne ve statistice dopravní nehodovosti.

Podívejme se na tuto problematiku ale z opačné strany, jinými slovy: definujme si, co to vlastně je dopravní nehoda. Podle zákona [14], je dopravní nehodou událost v provozu na pozemních komunikacích, např́iklad havárie nebo srážka, která se stala nebo byla započata na pozemní komunikaci a při níž dojde $\mathrm{k}$ usmrcení nebo zranění osoby nebo ke škodě na majetku v př́mé souvislosti s provozem vozidla v pohybu - viz § 47, odstavec 1 tohoto zákona [14]. V odstavci 4 uvádí zákon mj. následující povinnost: Dojde-li při dopravní nehodě k usmrcení nebo zranění osoby nebo $\mathrm{k}$ hmotné škodě převyšující žřjmě na některém ze zúčastněných vozidel včetně přepravovaných věcí částku $100000 \mathrm{Kč}$, jsou účastníci dopravní nehody povinni neprodleně ohlásit dopravní nehodu policistovi [14].

O hlášení dopravní nehody v souvislosti s usmrcením nebo zraněním osoby již řeč byla a obvykle $\mathrm{k}$ tomu dochází. Co se týče hlášení nehody s hmotnou škodou na vozidlech, závisí pak na rozhodnutí a dohodě samotných účastníků dopravní nehody. Nicméně často dochází také k dopravním nehodám, kdy dojde k poškození majetku třetí osoby, součásti pozemní komunikace atp. Zákon [14] na takovou událost myslí v odstavci $5 \S 47$ (upraveno): Povinnost ohlásit dopravní nehodu platí i v př́padě, kdy při dopravní nehodě dojde ke hmotné škodě na majetku třetí osoby a dojde k poškození nebo zničení součásti nebo př́íslušenství pozemní komunikace.

Pokud se jedná o viditelné poškození, lze opět předpokládat, že k nahlášení nehody dojde. Ale jak je to s hlášením dopravních nehod, dojde-li k nepatrnému poškození (např. při pojíždění zvýšeného obrubníku), jehož následky mohou být žretelné až po opakovaném poškozování (pojíždění)? V mnoha př́ípadech tuto skutečnost řidič ani nezaregistruje a pokračuje v jízdě. Viníkem však nemusí být vždy pouze samotný řidič, ale na vině mohou být také chybně navržené stavební prvky (malý poloměr nároží, nedostatečná šiřrka jízdního pruhu atp.). K odhalování takových případů, kdy vlivem nevhodně navrženého stavebního prvku dochází $\mathrm{k}$ jeho postupnému poškozování, lze s výhodou použít právě videoanalýzu konfliktních situací.

Vždy je však nutné mít na paměti, zda se opravdu jedná o pravidelné poškozování těchto stavebních prvků, anebo došlo na tomto místě k ojedinělé dopravní nehodě, poškození vlivem zimní údržby, nebo 
se jedná o výjimečné situace zaprríčiněné zakrytím sledovaného prvku sněhem, kdy tento prvek není pro řidiče zřetelně viditelný a může dojít k ojedinělému najetí např. na obrubník (viz obr. 5 a 6 ).
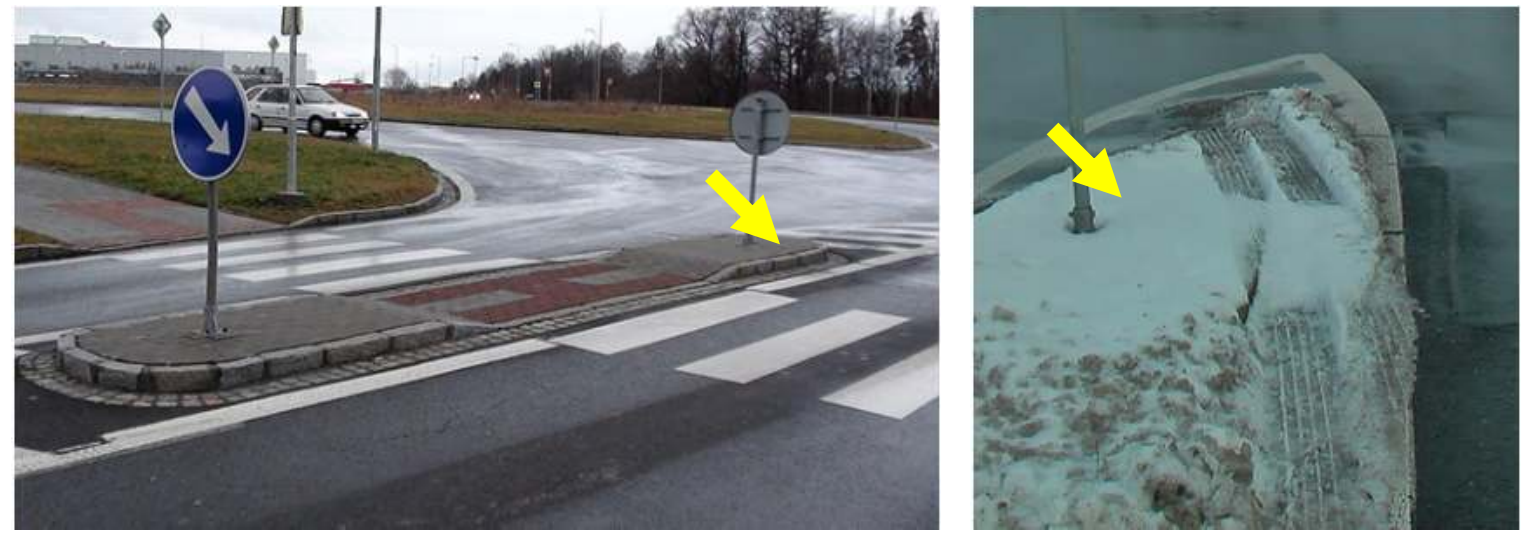

Obr. 5 Srovnání letního a zimního záběru na ochranný ostrůvek [8]
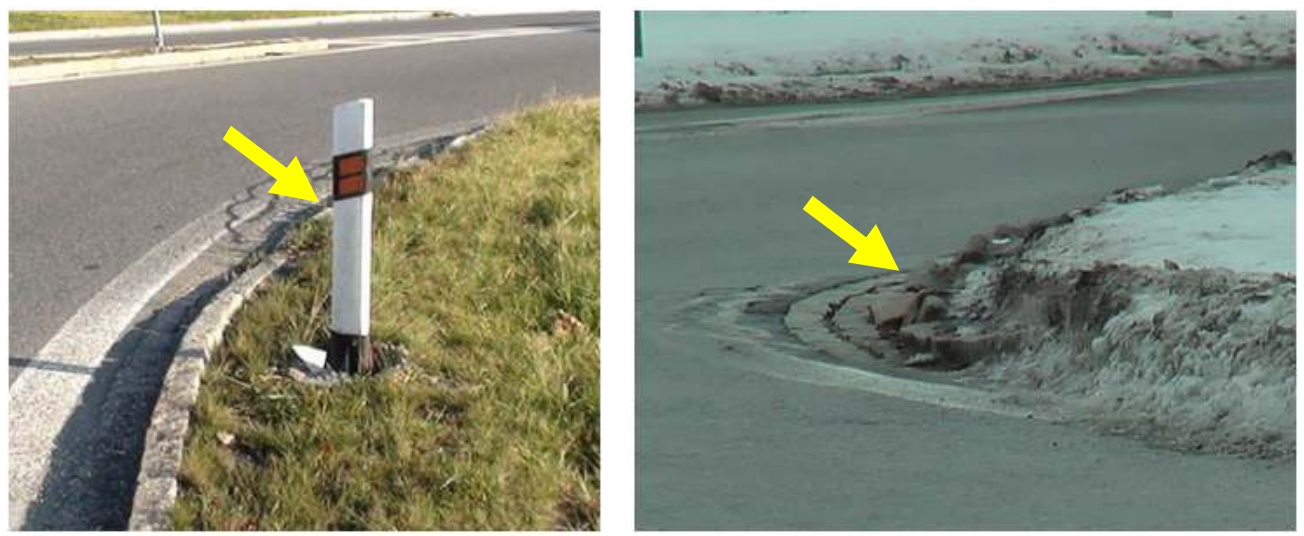

Obr. 6 Srovnání letního a zimního záběru na výjezd z okružní křižovatky; šipkou je označené stejné místo (z jiného úhlu) - vpravo již ovšem s chybějícím směrovým sloupkem [8]

Konfliktní situace způsobené pouze chybným chováním řidiče lze řešit například větší osvětou, která osvětlí správný způsob jízdy a chování na okružních křižovatkách. Tato osvěta však nemůže být zaměřena pouze na nové řidiče (tj. $v$ autoškolách), ale i na stávající zkušenější řidiče, kteří tímto způsobem budou mj. upozorněni na novinky v pravidlech silničního provozu. Konfliktní situace způsobené chybně navrženou křižovatkou lze sice řešit její vhodnou úpravou, je však nutné mít vždy na paměti, že jakákoliv, byt' pozitivní, změna může mít za následek vznik dalšího problému, resp. problémů (a mnohdy závažnějších).

Sledování konfliktních situací v silničním provozu má jistě svůj opodstatněný význam. Vždy je lépe problémům (tj. zde dopravním nehodám) předcházet, než poté řešit jejich následky, které mohou být a obvykle bývají, poměrně závažného charakteru (úmrtí, zranění, věcná škoda).

\section{PODĚKOVÁNÍ}

Výsledky uvedené v tomto př́spěvku vznikly za finanční podpory projektu výzkumu a vývoje č. CG911-008-910 „Vliv geometrie stavebních prvků na bezpečnost a plynulost provozu na okružních křižovatkách a možnost predikce vzniku dopravních nehod" Ministerstva dopravy ČR [9]. 


\section{Použitá literatura}

[1] AMBROS, Jiří a Josef KOCOUREK. Metodika sledováni a vyhodnocováni dopravnich konflikti̊. Brno: Centrum dopravního výzkumu, v.v.i., 2013, 41 s. ISBN 978-80-86502-62-5

[2] BENNET, C. T. Accident at Urban Junctions. The Journal of the Institution of Highway Engineers 18. 1971, č. 7

[3] BAKER, W. T. An Evaluation the Traffic Conflicts Technique. Highway Research Record. Washington, 1972, č. 384

[4] FOLPRECHT, Jan. Metoda sledování a hodnocení konfliktních situací v silniční dopravě a její význam pro zvyšování bezpečnosti provozu. In: Mezinárodni vědecká konference při př́ležitosti 50 let působeni V̌̌B v Ostravě: Sekce 19: Doprava. Ostrava: VŠB-TU Ostrava, 1995 , s. $227-231$.

[5] FOLPRECHT, Jan a Vladislav KŘIVDA. Organizace a ř́zení dopravy I. Ostrava: VŠB-TU Ostrava, 2006, 158 s. ISBN 80-248-1030-1.

[6] HAYWARD, J. C. Near-miss Determination through Use of a Scale of Danger. Highway Research Record. Washington, 1972, č. 384

[7] KOCOUREK, Josef. Sledování dopravních konfliktı̊ jako ukazatelů bezpečnosti dopravy. Silnice a železnice. 2010, č. 3, s. P8-P12. ISSN 1801-822X.

[8] KŘIVDA, Vladislav. Využití videoanalýzy konfliktnich situaci při hodnoceni nevhodně navržených stavebnich prvků na křižovatkách. Ostrava, 2012. 100 s. Habilitační práce. VŠBTU Ostrava, Fakulta strojní

[9] MAHDALOVÁ, Ivana. Viv geometrie stavebnich prvků na bezpečnost a plynulost provozu na okružnich křžovatkách a možnost predikce vzniku dopravních nehod. Projekt výzkumu a vývoje č. CG911-008-910 Ministerstva dopravy ČR. Řešitel Katedra dopravního stavitelství, Fakulta stavební, VŠB - Technická univerzita Ostrava. 2009 - 2010

[10] PERKINS, S. R. a J. I. HARRIS. Traffic Conflicts Characteristics - Accident Potential at Intersections. Highway Research Record. Washington, 1968, č. 225

[11] RUSTAM, K. a B. E. SABEY. Accident and Traffic Conflicts at Junction. TRRL Report. Crowthorne, Bereshire, 1972, č. 514

[12] SLABÝ, Petr. Aktivace výzkumu dopravní nehodovosti v letech 1996 - 1999. Silnični obzor. 1997, č. 2. ISSN 0322-7154.

[13] ZAJÍC, Pavel. Analýza provozu na pozemnich komunikacích pomocí automatizovaného hodnoceni videozáznamu. Ostrava, 2011. 14 s. Teze disertační práce. VŠB-TU Ostrava, Fakulta strojní.

[14] Zákon č. 361/2000 Sb. o provozu na pozemních komunikacích a o změnách některých zákonů (zákon o silničním provozu), ve znění pozdějších předpisů. In: Sbirka zákonů České republiky. 2000 . 